\title{
Brown Root Rot Disease in American Samoa's Tropical Rain Forests ${ }^{1}$
}

\author{
Fred E. Brooks ${ }^{2}$
}

\begin{abstract}
Phellinus noxius (Corner) Cunningham causes root and lower stem rot of woody plants throughout the South Pacific region. Its hosts include rubber, mahogany, cacao, and many timber, fruit, and landscape trees. Though endemic to the Tropics, no reports were found describing brown root rot disease in native forests, exclusively. Incidence, distribution, and host range of $P$. noxius were measured in primary and secondary rain forests on Tutuila Island, American Samoa. Phellinus noxius was recorded in 19 of 20 strip transects and 1.2-ha established plots and in all vegetation types, infecting 37 tree species in 30 genera and 22 families. Species most affected were Myristica fatua, Dysoxylum samoense, and Hibiscus tiliaceus-25, 16, and 10\%, respectively. Of 62 infection centers, 33 contained the same tree species and 13 were dominated by a single species. The fewest infections were recorded at primary montane and ridge top sites. Regenerating secondary valley sites had the highest incidence of disease and greatest number of infection centers. Infection centers at these disturbed sites also contained more trees on average than centers at primary sites. Disease incidence was influenced more by human disturbance than by vegetation type, topography, stem diameter, stem density, or soil type. The disturbed sites also appeared to lack the species richness of mature sites. This agrees with other host/pathogen associations, such as Douglas-fir/P. weirii and hardwood/P. noxius plantations, where disease incidence and spread was higher in species-poor than in species-rich stands.
\end{abstract}

Brown Root rot disease, caused by Phellinus noxius (Corner) Cunningham, has been reported throughout the Pacific and Southeast Asia as a cause of tree decline and mortality (McKenzie 1996). The name brown root rot refers to a brown to black mycelial crust formed by the fungus on the surface of infected roots and stem bases (Chang and Yang 1998). However, $P$. noxius is generally considered a white rot fungus because of its

\footnotetext{
${ }^{1}$ Funded by the U.S. Department of Agriculture, Cooperative State Research, Education and Extension Service (USDA CSREES) (Project SAM-020) and the Division of Forestry, American Samoa Community College Land Grant Program. Manuscript accepted 3 January 2002.

2 Plant Pathologist, American Samoa Community College, Land Grant Program, P.O. Box 5319, Pago Pago, American Samoa 96799 (phone: 684-699-1394; fax: 684-699-5011; E-mail: fredbrooks@hotmail.com).
}

Pacific Science (2002), vol. 56, no. 4:377-387 (C) 2002 by University of Hawai'i Press All rights reserved ability to degrade lignin, a basic component of wood (Adaskaveg and Ogawa 1990, Chang and Yang 1998).

Most of the literature on $P$. noxius describes root and crown rot of plantation crops such as hoop pine, Araucaria cunninghamii Ait. ex D. Don (Bolland 1984); cacao, Theobroma cacao L. (Thrower 1965); rubber, Hevea brasiliensis (Willd. ex Adr. de Juss) Muell. Arg. (Nandris et al. 1987); mahogany, Swietenia macropbylla King (Singh et al. 1980); and Cordia alliodora (Ruiz. \& Pav.) Oken (Neil 1986). Nonnative trees introduced in reforestation projects and infected by $P$. noxius include C. alliodora (Neil 1986), S. macrophylla, and Gmelina arborea Roxb. (Ivory 1990). Woody perennials in fruit orchards and landscape plantings have also been documented as susceptible to brown root rot (Hodges and Tenorio 1984, Chang 1995, Ann et al. 1999). Chang and Yang (1998) listed 60 fruit, forest, and ornamental plant species infected by the fungus in Taiwan. I found no published reports limited to $P$. noxius damage in native tropical forests. 
Currently in American Samoa there is little concern over occasional fruit or landscape trees killed by brown root rot disease. Many farmers have lost breadfruit trees, Artocarpus altilis (S. Parkinson) Fosb., to the disease, first reported in American Samoa as charcoal crown rot, caused by Corticium sp. (Trujillo 1971), but later recognized as $P$. noxius by Hodges and Tenorio (1984). Due to limited land and a rapidly increasing population, however, farmers are moving up valleys and ridges into native forests (Volk et al. 1992). Brown root rot disease is present in the forests of American Samoa (F. Brooks, pers. obs.) and recently cleared planting sites may be infested with the fungus, causing death of agroforest species, including breadfruit and citrus. Phellinus noxius spreads by root contact and may persist in colonized roots and stumps for more than $10 \mathrm{yr}$ after death of the host (Chang 1996). The purpose of this study was to determine the incidence, distribution, and host range of $P$. noxius in primary and secondary forests on Tutuila, the main island of American Samoa.

\section{MATERIALS AND METHODS}

\section{Study Sites}

All sites were on Tutuila Island, located at $14^{\circ} 18^{\prime} \mathrm{S}$ latitude and $170^{\circ} 41^{\prime} \mathrm{W}$ longitude. Average annual temperature is $26.4^{\circ} \mathrm{C}$ and annual rainfall ranges from $2500 \mathrm{~mm}$ on the Tafuna Plain to over $6000 \mathrm{~mm}$ on Matafao Peak. Tutuila's eroded volcanic ridges and valleys cover $137 \mathrm{~km}^{2}, 65 \%$ of which consists of steep (>30\%), heavily forested slopes (Wingert 1981). Slopes in most rain forests are from 40 to $70 \%$ with areas exceeding $100 \%$ (Webb and Fa'aumu 1999). Most of the Territory's estimated 65,000 inhabitants live on Tutuila.

The 20 survey sites selected were both accessible and large enough for transects. They included five primary (late successional) vegetation types: montane forest, ridge, slope and valley lowland forest, and littoral forest (Whistler 1994). Three examples of secondary (disturbed or early successional) vegetation were also surveyed. The total area sampled was 8.8 ha, of which 1.2 ha was secondary forest and 7.6 ha primary forest.

The littoral forest, on or just inland from the coast, is characterized by Barringtonia asiatica (L.) Kurz and other salt-tolerant plant species dispersed by the sea or by ocean birds (Cole et al. 1988). Lowland forest, also called tropical rain forest or high forest, covers most of the island and was divided by Whistler (1994) into coastal, valley, and ridge vegetation types found below $350 \mathrm{~m}$. Differences in soil, topography, and elevation and natural and human-caused disturbances affect these vegetation types (Whistler 1994, Webb et al. 1999). Indigenous lowland forest tree species include Syzygium inophylloides (A. Gray) C. Muell., Calophyllum neo-ebudicum Guillaumin, Canarium vitiense A. Gray, C. harveyi Seem., Diospyros samoensis A. Gray, and Myristica fatua Houtt. Montane forest occurs at elevations above $350 \mathrm{~m}$ and is periodically altered by humans or natural events, such as hurricanes and landslides. Predominant montane species include Dysoxylum buntii Merr., Syzygium samoense (Burkill) Whistler, and Crossostylis biflora Forst.

The survey also included the Tafuna Plain lowland forest, a remnant of tropical forest that once covered most of the large, relatively flat Tafuna Plain. Dominant tree species in the Tafuna forest are Planchonella samoensis $\mathrm{H}$. J. Lam ex Christoph., Pometia pinnata Forst., and Dysoxylum samoense A. Gray (Webb et al. 1999). Though reduced to approximately 8 ha and surrounded by human habitation, almost $20 \%$ of the 425 indigenous angiosperms in American Samoa occur in this species-rich community (Whistler 1993). Further, because large areas of the plain are still agroforest, the incidence of $P$. noxius in this remaining stand was of interest. The Tafuna lowland forest is also a target of renewed conservation efforts based on the work of Volk et al. (1992), Whistler (1993), and others.

To determine if the incidence and distribution of $P$. noxius varied in disturbed areas, secondary forest sites (Whistler 1994) were included in the survey. Key indigenous species characteristic of forest disturbance include Rhus taitensis Guillemin, Hibiscus tilia- 
ceus L., Macaranga barveyana (Muell. Arg.) Muell. Arg., and M. stipulosa Muell. Arg. (Webb et al. 1999).

\section{Soils}

Descriptions of soil types were based on work by the USDA Soil Conservation Service (Nakamura 1984). Soils at 12 of 18 sites are derived from Fagasa family-Lithic Hapludolls-Rock outcrop. Approximately $55 \%$ of this soil unit, the Fagasa family, is found on ridges and slopes from 70 to $130 \%$. These soils are formed from igneous bedrock, are well drained, and are fairly deep. Lithic Hapludolls are cobbly and clayey, shallow, and well drained and form $20 \%$ of this soil type. Very steep to vertical outcroppings of igneous rock make up another $15 \%$ of this unit, followed by small areas of talus, landslides, and other soils. Aua very stony silty clay loam was present at four of the survey sites, on 30 to $60 \%$ slopes and below $150 \mathrm{~m}$. Permeability is moderately rapid, but danger of erosion on steeper slopes due to runoff is severe. The soil unit at two disturbed sites in Malaeimi Valley was Leafu silty clay. This deep, alluvial, poorly drained soil is generally found on valley floors and near streams. Water tables tend to be high, 75-150 cm, leading to wet soils and occasional flooding. In the Tafuna Plain lowland forest the soil unit covering the lava beds is Tafuna extremely stony muck. It is deep, well drained, and broken by extensive outcroppings of lava stones. Soils at the Pago Pago Airport, where the Tafuna Plain meets the sea, are Troporthents. They have been disturbed by cutting, grading, and filling and consist of sand, gravel, cobbles, and fine-textured soil. Water erosion is minimal due to moderate soil permeability and slow to medium runoff.

\section{Survey Methods}

Incidence and distribution of $P$. noxius was determined by strip transects (Greenwood 1996) and fixed plots (Webb and Fa'aumu 1999). At least two strip transects were surveyed in each primary vegetation type by pacing off $245 \mathrm{~m}$ with a measuring wheel
(Measure Meter, model MM-50, Rolatape, Spokane, Washington). Workers examined every tree within $5 \mathrm{~m}$ on either side of the wheel, producing a $2450-\mathrm{m}^{2}(0.25$-ha) transect. Information collected in all surveys included tree species with signs of $P$. noxius infection, tree location within transects, infection centers, and tree diameter at breast height $(\mathrm{dbh})$. Infection centers were defined as two or more infected trees, each within 3 $\mathrm{m}$ of the nearest infected tree.

Four permanent American Samoa Government, Department of Marine and Wildlife Resources (DMWR) research plots were also surveyed for $P$. noxius. These plots, located at Amalau, Vatia, Maloata, and Alava, were established in 1998 by Webb and Fa'aumu (DMWR, unpubl. data). Plots measured 100 by $120 \mathrm{~m}(1.2 \mathrm{ha})$ and were located to include ridge top, slope, and valley lowland forest habitats. All sites except Maloata included a stream bottom, and the Amalau site was located below ridgeline. Trees in these plots with a dbh $\geq 10 \mathrm{~cm}$ have been identified, measured, and tagged. This provided information on stand density, species richness and distribution, and diameter class for comparison with data collected in the surveys. Spatial distribution of P. noxius in DMWR plots was analyzed using Spatial Point Pattern Analysis (SPPA ver. 1.1.1 [Haase 1995]).

\section{Pathogen}

Trees were considered infected by $P$. noxius if two or more of the following signs were present. On most trees a thick mycelial crust enveloped infected roots and the base of the stem up to $2 \mathrm{~m}$ (Bolland 1984, Hodges and Tenorio 1984, Ivory 1990). The white, expanding margin of the crust was associated with underlying sapwood discoloration (Thrower 1965, Singh et al. 1980, Hodges and Tenorio 1984, Nandris et al. 1987). Fine mats of mycelium were present between infected bark and sapwood, and underlying colonized heartwood eventually became white, spongy, dry, and permeated with reddish brown or dark lines (Singh et al. 1980, Nandris et al. 1987, Ivory 1990, Chang 1995, Nicole et al. 1995). Fruiting bodies (sporo- 
carps) occasionally were present on standing and fallen trees. They were either shelflike (reflexed), growing flat along the undersides of fallen trees (effused), or a combination of both (effused-reflexed). The sterile upper surface of sporocarps was medium brown to black, rough, and irregularly zoned. The fertile pore surface was usually gray brown to umbrinous (Corner 1932, Fidalgo 1968, Pegler and Waterston 1968).

When E. J. H. Corner first described Fomes noxius in 1932, he separated it from Fomes lamaensis (Murr.) Sacc. \& Trott. mainly on microscopic characteristics and the parasitic ability of the former. Both species are present in the Samoas (McKenzie 1996) and are now in the genus Phellinus. Phellinus lamaensis (Murrill) Heim has since been described by Fidalgo (1968) as either parasitic or saprophytic. Phellinus lamaensis may tentatively be distinguished from $P$. noxius in the field by the ochre-colored expanding margin of the sporocarp and lack of a mycelial crust; the margin of the $P$. noxius sporocarp is usually creamy white and it commonly grows from a mycelial crust (Corner 1932). Microscopically, $P$. lamaensis has conical, reddish brown hymenial setae projecting conspicuously into the pores; hymenial setae are absent in P. noxius (Corner 1932, Fidalgo 1968, Pegler and Waterston 1968).

\section{RESULTS}

\section{Distribution and Frequency}

Brown root rot disease was observed at 19 of the 20 sites surveyed on Tutuila Island (Table 1). It was not detected in a strip transect next to the Pago Pago Airport runway, a disturbed area dominated by $H$. tiliaceus and nonnative Leucaena leucocephala (Lam.) de Wit. Phellinus noxius was most prevalent in the three secondary (disturbed) valley sites, composing $41 \%$ of all infections. The Malaeimi Valley soil (Table 1) is poorly drained silty soil with areas that remain wet for much of the year. Few infected trees were observed in the wettest areas of the Malaeimi II transect (Figure $1 a, 120$ to $245 \mathrm{~m}$ ), but $P$. noxius was heavily distributed along a dry streambed of loose,
TABLE 1

Vegetation and Soil Types, and Percentage of Brown Root Rot Disease (Phellinus noxius) for Four Established Plots and 16 Strip Transects on Tutuila Island, American Samoa

\begin{tabular}{lllc}
\hline \hline & $\begin{array}{c}\text { Vegetation }^{\text {Type }} \\
\text { Site }^{a}\end{array}$ & Soil $^{c}$ & P. noxius $^{d}$ \\
\hline 1. Alava, DMWR & $\mathrm{R}, \mathrm{S}, \mathrm{V}$ & 4 & 5.6 \\
2. Amalau, DMWR & $\mathrm{S}, \mathrm{V}$ & 4,2 & 8.6 \\
3. Maloata, DMWR & $\mathrm{R}, \mathrm{S}$ & 4 & 7.1 \\
4. Vatia, DMWR & $\mathrm{R}, \mathrm{S}, \mathrm{V}$ & 4 & 7.1 \\
5. Matafao Peak & $\mathrm{M}$ & 4 & 0.6 \\
6. Maatula & $\mathrm{M}$ & 4 & 1.2 \\
7. Olo & $\mathrm{R}$ & 2 & 1.5 \\
8. Tuasina & $\mathrm{R}$ & 4 & 1.2 \\
9. Faga'alu & $\mathrm{S}$ & 4 & 2.2 \\
10. A'asutuai & $\mathrm{S}$ & 4 & 2.8 \\
11. Malaeloa & $\mathrm{V}$ & 8 & 2.5 \\
12. Nu'uuli & $\mathrm{V}$ & 2 & 3.1 \\
13. Vatia I & $\mathrm{L}$ & 2 & 4.3 \\
14. Taputapu & $\mathrm{L}$ & 4 & 2.5 \\
15. Tafuna & $\mathrm{P}$ & 32 & 7.4 \\
16. Vatia II & $2^{\circ} \mathrm{R}$ & 4,2 & 1.2 \\
17. Maloata & $2^{\circ} \mathrm{V}$ & 4 & 15.1 \\
18. Malaeimi I & $2^{\circ} \mathrm{V}$ & 8 & 18.8 \\
19. Malaeimi II & $2^{\circ} \mathrm{V}$ & 8 & 7.1 \\
20. Pago Pago Airport & $2^{\circ} \mathrm{P}$ & 33 & 0 \\
\hline
\end{tabular}

${ }^{a}$ DMWR, American Samoa Government, Department of Marine and Wildlife Resources 1.2-ha plots. Other sites listed are 0.25 -ha strip transects.

${ }^{b}$ Vegetation types (Whistler 1994): R, ridge; S, slope; V, valley bottom; $\mathrm{M}$, montane (>350 m elevation); L, littoral; P, Tafuna Plain; $2^{\circ}$, secondary or disturbed sites.

${ }^{c}$ Soil type and slope (see text for description): 4, Lithic Hapludolls-Rock outcrop association, very steep; 2, Aua very stony silty clay loam, 30-60\%; 32, Tafuna extremely stony muck, $3-15 \%$; 8 , Leafu silty clay, $0-3 \%$; 33, Troporthents, $0-6 \%$ (Nakamura 1984).

${ }^{d}$ Percentage of the total number of trees infected with Phellinus noxius from all sites (324). Note: area of DMWR plots is five times greater than that of strip transects.

rocky soil in the Malaeimi I transect (Figure $1 b, 160$ to $245 \mathrm{~m})$. The Maloata Valley transect was perpendicular to and bisected by a perennial stream. Though $P$. noxius was recorded near the stream, most of the infected trees were located on steep slopes away from water (Figure 1c).

The Tafuna Plain lowland forest transects had $10 \%$ of the infected trees in strip surveys (Figure $1 d$ ), followed by littoral (9\%), primary valley $(8 \%)$, slope $(7 \%)$, ridge top $(4 \%)$, and montane $(3 \%)$ sites. The disturbed ridge and airport were single transect sites. 


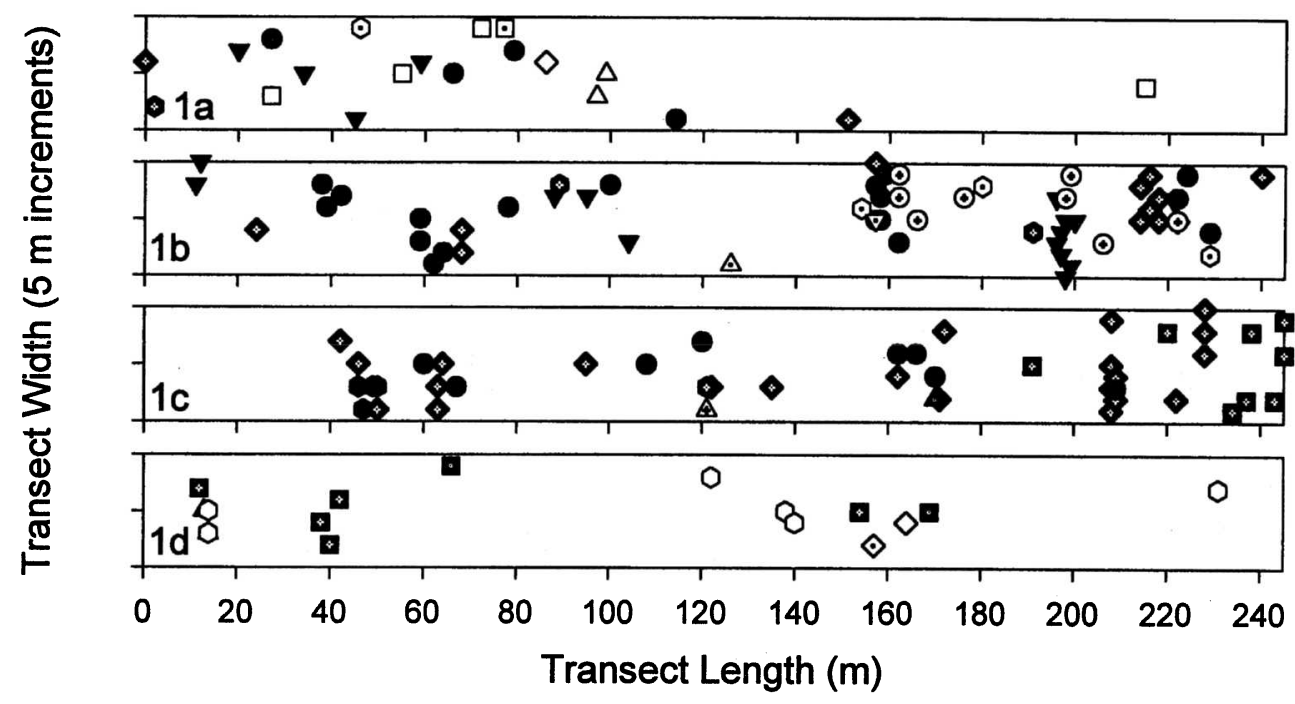

$\begin{array}{ll}\text { - } & \text { Barringtonia samoensis } \\ \text { Cananga odorata } \\ \odot \text { Dysoxylum samoense } \\ - \text { Ficus tinctoria } \\ \text { - Hibiscus tiliaceus } \\ \odot \quad \text { Inocarpus fagifer } \\ \odot \quad \text { Intsia bijuga }\end{array}$

Macaranga harveyana
- Macaranga stipulosa
- Morinda citrifolia
$\Delta$ Pipturus argenteus
- Planchonella samoensis
$\diamond$ Pometia pinnata

๑ Samanea saman

- Spondias dulcis

$\Delta$ Syzygium inophylloides

$\Delta$ Terminalia richii

0 Unidentified

$\diamond$ Pometia pinnata

FIgURE 1. Plots of tree species in strip transects at secondary (disturbed) lowland forest sites, Tutuila Island, American Samoa. Each transect was 10 by $245 \mathrm{~m}(0.25 \mathrm{ha})$; symbols represent infected tree species and their approximate location within transects. Sites include (1a) Malaeimi Valley II, (1b) Malaeimi Valley I, (1c) Maloata Valley, and (1d) Tafuna Plain.

\section{Host Range}

Twenty-five of 324 infected trees from all sites could not be identified, mainly due to their advanced state of decay. The 299 identified host trees included 37 species in 30 genera and 22 families (Table 2). Of the 299 diseased, identified trees at all sites, $M$. fatua was the most commonly affected (25\%), followed by $D$. samoense $(16 \%)$ and $H$. tiliaceus $(10 \%)$ (Table 2). All trees in the 16 strip transects were not identified, but in the four DMWR plots $M$. fatua was the most abundant $(31 \%)$, followed by $H$. tiliaceus $(14 \%)$ (DMWR, unpubl. data). Dysoxylum samoense, common in young secondary forests (Whistler 1994), composed only $0.4 \%$ of tree species in the four primary forest (DMWR) plots

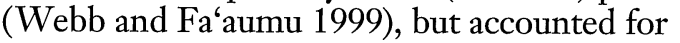

over $30 \%$ (35 of 150 trees) of the infected trees in two secondary valley sites.

\section{Infection Centers}

Sixty-one percent of all trees with brown root rot disease were in clusters of 2-10 infected trees. The distribution of infected trees was significantly clumped in all DMWR plots except Alava, according to Ripley's $K$-function based on a Monte-Carlo simulation with 1000 iterations (Ripley 1981, Haase 1995) (Figure 2). Of the 62 infection centers in both permanent and strip transect plots, $53 \%$ contained trees of the same species, and one species was in the majority in $19 \%$ of the centers. For example, one center of eight infected trees at a disturbed valley site (Figure 1b) contained only $H$. tiliaceus, and the four in- 
TABLE 2

Tree Species Infected by Phellinus noxius on Tutuila Island, American Samoa, January to May 2001

\begin{tabular}{|c|c|c|}
\hline Host $^{a}$ & No. ${ }^{b}$ & $\mathrm{dbh}(\mathrm{cm})^{c}$ \\
\hline \multicolumn{3}{|l|}{ Anacardiaceae } \\
\hline $\begin{array}{l}\text { Rhus taitensis Guillemin } \\
\text { Spondias dulcis L. }\end{array}$ & 11 & $\begin{array}{l}(9-86) 45 \\
(26-79) 63\end{array}$ \\
\hline \multicolumn{3}{|l|}{ Annonaceae } \\
\hline Cananga odorata (Lam.) Hook \& Thoms. & 8 & $(13-44) 29$ \\
\hline $\begin{array}{l}\text { Apocynaceae } \\
\text { Cerbera mangbas } \mathrm{L} \text {. }\end{array}$ & 2 & $(8.3-38.5) 23$ \\
\hline \multicolumn{3}{|l|}{ Barringtoniaceae } \\
\hline Barringtonia asiatica $(\mathrm{L}.) \mathrm{Kurz}$ & 3 & $\begin{array}{l}(4.5-64.5) 25 \\
(115-72) 25\end{array}$ \\
\hline Barringtonia samoensis A. Gray & 8 & $(11.5-72) 25$ \\
\hline \multicolumn{3}{|l|}{ Boraginaceae } \\
\hline Cordia aspera Forst. f. & 1 & 13.5 \\
\hline \multicolumn{2}{|l|}{ Burseraceae } & $(6-41.5) 18$ \\
\hline \multicolumn{3}{|l|}{ Clusiaceae } \\
\hline Calophyllum neo-ebudicum Guillaumin & 6 & $(58-190) 132$ \\
\hline \multicolumn{3}{|l|}{ Combretaceae } \\
\hline Terminalia ricbii A. Gray & 1 & 17 \\
\hline \multicolumn{3}{|l|}{ Ebenaceae } \\
\hline Diospyros samoensis A. Gray & 1 & 5 \\
\hline \multicolumn{3}{|l|}{ Euphorbiaceae } \\
\hline Flueggea flexuosa Marg. & 3 & $(12-15) 13.5$ \\
\hline Glocbidion ramiflorum Forst. & 1 & \\
\hline Macaranga barveyana (Muell. Arg.) Muell. Arg. & 20 & $(2-34) 15$ \\
\hline Macaranga stipulosa Muell. Arg. & 10 & (14-38) 24 \\
\hline \multicolumn{3}{|l|}{ Fabaceae } \\
\hline Adenanthera pavonina $\mathrm{L}$. & 1 & \\
\hline Inocarpus fagifer (Parkinson) Fosb. & 9 & $(5-89) 31$ \\
\hline Intsia bijuga (Colebr.) Kuntze & 7 & $(2.5-57) 20$ \\
\hline Samanea saman (Jacq.) Merr. & 1 & 93 \\
\hline \multicolumn{3}{|l|}{ Hernandiaceae } \\
\hline Hernandia nymphaeifolia (Presl) Kub. & 1 & 38 \\
\hline
\end{tabular}

fection centers in the Tafuna Plain transects each consisted of a single tree species. The highest number of infection centers occurred in the disturbed valley sites: Malaeimi I, Maloata, and Malaeimi II, with 10, 10, and 5 centers, respectively. Malaeimi I and $\mathrm{Ma}$ loata had infection centers with the greatest number of trees (Figure 1b,c). The center covering the largest area, $100 \mathrm{~m}^{2}$, was also in Malaeimi I.

\section{Diameter Class}

The total number of trees with a dbh $\geq 10 \mathrm{~cm}$ was determined for the DMWR plots Alava, Amalau, and Vatia (Webb and Fa'aumu 1999). Trees with a dbh $>30 \mathrm{~cm}$ composed $19 \%$ of all trees but $44 \%$ of infected trees (Table 3). Trees in strip transects were not counted and only the dbh of infected trees was measured: $26 \%$ of infected trees were in diameter classes $>30 \mathrm{~cm}$ and $24 \%$ had a dbh $<10 \mathrm{~cm}$.

\section{Pathogen}

Characteristics of $P$. noxius sporocarps were within limits described by Corner (1932) and Fidalgo (1968). A mycelial crust approximately $1.0 \mathrm{~cm}$ thick was present on the upper roots, lower stem, or both, of most infected trees and was generally between 0.5 and $1.0 \mathrm{~m}$ in height. At the Malaeimi II site, however, crusts were $3.0 \mathrm{~m}, 4.3 \mathrm{~m}$, and $4.85 \mathrm{~m}$ 
TABLE 2 (continued)

\begin{tabular}{|c|c|c|}
\hline Host $^{a}$ & No. ${ }^{b}$ & $\mathrm{dbh}(\mathrm{cm})^{c}$ \\
\hline \multicolumn{3}{|l|}{ Malvaceae } \\
\hline Hibiscus tiliaceus $\mathrm{L}$. & 29 & $(6-68) 21$ \\
\hline \multicolumn{3}{|l|}{ Meliaceae } \\
\hline Dysoxylum samoense A. Gray & 45 & $(2-160) 25$ \\
\hline \multicolumn{3}{|l|}{ Moraceae } \\
\hline Ficus obliqua Forst. f. & 3 & $(89-123) 10$ \\
\hline Ficus tinctoria Forst. f. & 1 & 5 \\
\hline Ficus sp. & 1 & 5 \\
\hline \multicolumn{3}{|l|}{ Myristicaceae } \\
\hline Myristica fatua Houtt. & 69 & $(3-140) 19$ \\
\hline \multicolumn{3}{|l|}{ Myrtaceae } \\
\hline Syzygium inophylloides (A. Gray) C. Muell. & 2 & $(15-51) 33$ \\
\hline Syzygium sp. & 1 & 19 \\
\hline \multicolumn{3}{|l|}{ Rhizophoraceae } \\
\hline Crossostylis biflora Forst. & 1 & 17 \\
\hline \multicolumn{3}{|l|}{ Rubiaceae } \\
\hline Morinda citrifolia $\mathrm{L}$. & 3 & $(2.5-10) 5$ \\
\hline Neonauclea forsteri (Seem. ex Havil.) Merr. & 1 & 102 \\
\hline \multicolumn{3}{|l|}{ Sapotaceae } \\
\hline Planchonella grayana St. John & 2 & $(57-83) 66$ \\
\hline Planchonella samoensis H. J. Lam ex Christoph. & 20 & $(5-110) 42$ \\
\hline \multicolumn{3}{|l|}{ Sapindaceae } \\
\hline Elattostachys falcata (A. Gray) Radlk. & 2 & $(33.4-35) 34$ \\
\hline Pometia pinnata Forst. & 3 & $(5-22) 12$ \\
\hline \multicolumn{3}{|l|}{ Urticaceae } \\
\hline Pipturus argenteus (Forst. f.) Wedd. & 2 & $(11-22) 17$ \\
\hline Unidentified & 25 & $(4-80) 24$ \\
\hline
\end{tabular}

high on $M$. fatua, $C$. odorata, and D. samoense, respectively. No tree infections recorded during this survey were attributed to $P$. lamaensis. Microscopic examination of wood decayed by $P$. noxius revealed the reddish brown lines to be both free and agglutinated fungal hyphae (Corner 1932).

\section{DISCUSSION}

Brown root rot disease is widely distributed in the tropical forests of Tutuila Island, American Samoa. It was found at all elevations and in all vegetation types and survey sites except one young, low-diversity stand of $H$. tiliaceus and $L$. leucocephala next to the Pago Pago Airport runway. The disease was discovered, however, in a less-disturbed continuation of the same forest outside the airport boundaries. Construction activities, including heavy grading and filling, may have disturbed or destroyed colonies of $P$. noxius in the transect area. Disease incidence at all sites was probably underreported, because $P$. noxius is usually transferred to healthy roots that touch diseased roots, stumps, or infected woody debris beneath the soil (Singh et al. 1980, Bolland 1984, Hodges and Tenorio 1984, Chang 1996). Early infections with no obvious aboveground signs or symptoms would not have been reported in this survey.

Disease incidence was lowest in montane and ridge-top transects, increasing slightly in primary valley, slope, coastal, and Tafuna Plain sites (Table 1). The number of infected trees in the secondary valley sites was more than twice that of the other sites. Webb and $\mathrm{Fa}^{6}$ aumu (1999) reported that catastrophic or repeated disturbances such as occur in secondary valleys affect stem density and species 

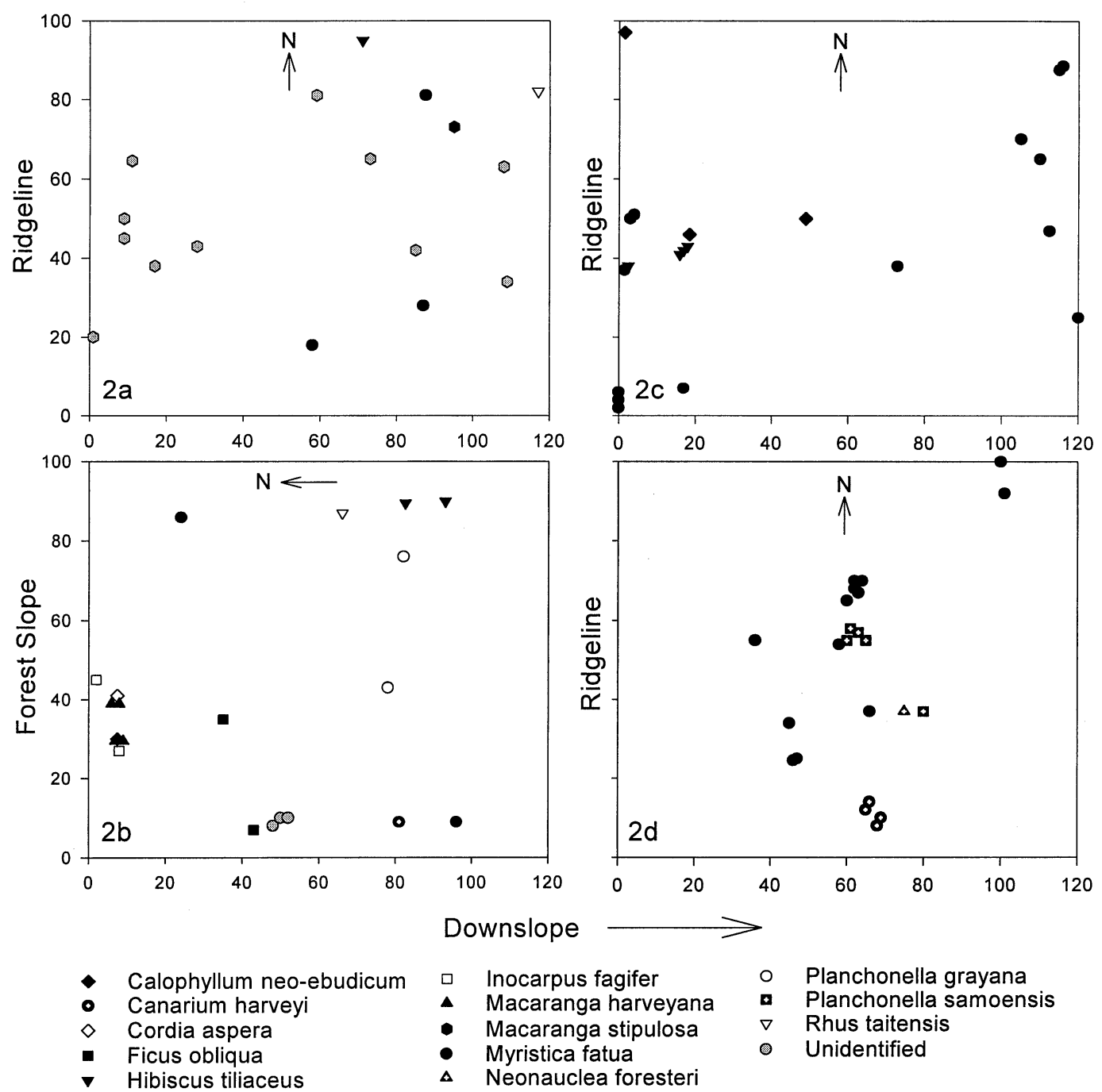

․ Inocarpus fagifer

- Planchonella grayana

- Macaranga harveyana

- Macaranga stipulosa

- Myristica fatua

- Planchonella samoensis

$\Delta \quad$ Neonauclea foresteri

$\nabla \quad$ Rhus taitensis

Unidentified

Figure 2. Diagram showing tree species in four permanent forest plots on Tutuila Island managed by the American Samoa Government, Department of Marine and Wildlife Resources (DMWR). Plots are relatively free of human disturbance and measure 100 by $120 \mathrm{~m}$ (1.2 ha). They include ridgelines, slopes, and valleys with the exception of Amalau, located below the ridgeline, and Maloata, which does not include a valley bottom. DMWR plots are located at (2a) Alava, (2b) Amalau, (2c) Maloata, and (2d) Vatia.

richness. These changes may in turn affect disease incidence (Bloomberg 1990). Other possible influences include edaphic factors, host susceptibility, aggregation of susceptible species, and virulence of the fungus.

Bloomberg (1990) cited high stocking levels (stem density) and the increased probability of root contact in Douglas-fir plan- tations on Vancouver Island, Canada, as a major cause of the spread of Phellinus weirii (Murill) R. L. Gilbertson. In tropical plantations, spread of $P$. noxius is usually within rows where spacing is closer, as opposed to between rows spaced farther apart (Neil 1986, Nandris et al. 1987). Webb et al. (1999) reported that stem densities in DMWR plots 
TABLE 3

Percentage of Trees in Three Diameter Classes at American Samoa Government, Department of Marine and Wildlife Resources Sites Alava, Amalau, and Vatia (Total) Followed by the Percentage of Infected Trees in Each Class Surveyed at These Sites (Infected)

\begin{tabular}{lccc}
\hline \hline Diameter Class $^{a}$ & $10-30 \mathrm{~cm}$ & $30-50 \mathrm{~cm}$ & $>50 \mathrm{~cm}$ \\
\hline Total & $81 \%$ & $13 \%$ & $6 \%$ \\
Infected & $55 \%$ & $21 \%$ & $23 \%$ \\
\hline
\end{tabular}

${ }^{a}$ Webb and Fa'aumu (1999).

were highest on ridges, possibly due to repeated thinning and shearing of trees caused by environmental disturbances, such as hurricanes and severe tropical storms. The opportunity for infection to spread by rootto-root contact should be greater on ridges where trees are closer together, but in the survey reported here it was one of the least affected areas.

Stem densities were lower in primary valley sites, but basal area measurements were higher than for either ridge or slope vegetation (Webb et al. 1999). In the same study on Douglas-fir stem densities, Bloomberg (1990) also cited large average tree diameters as an important factor in $P$. weirii advance due to large root systems. In the DMWR plots, trees with large diameters $(>50 \mathrm{~cm})$ were the least frequent but had the highest proportion of brown root rot disease (Table 3).

Ridge soils are generally moist and well drained (Nakamura 1984), a condition favoring P. noxius infection (Bolland 1984, Chang 1996). The heavily infested secondary valley sites, Malaeimi I and II, were reported to be wet, poorly drained soils with a high water table (Nakamura 1984). According to Chang (1996), however, only flooded soils significantly limit $P$. noxius survival in infected wood: at soil matrix water potentials lower than $-0.25 \mathrm{MPa}$, survival was $80-90 \%$ after 2 yr. Most infected trees at Malaeimi I were either located along a dry, stony, well-drained streambed, or associated with surface roots (Figure 1b). No infections were recorded from the wettest portion of the Malaeimi II strip transect (Figure 1a).
Species richness is greater on ridge tops than in other vegetation types of American Samoa (Webb et al. 1999). Nandris et al. (1987) suggested that mixed stands inhibit root rot in primary tropical forests due to different above- and belowground structures, ecology, and disease susceptibility. These conditions produce equilibrium between forest trees and fungi, with root rot maintained between 2 and 7\% (Nandris et al. 1987). In spite of high stem densities and soils more favorable to $P$. noxius, a greater diversity of tree species on ridge tops may be responsible for the lower disease incidence $(3.2 \%)$ and distribution of brown root rot disease in American Samoa.

The high number of infected trees in secondary valleys on Tutuila Island may be due to the relative abundance and aggregation of a few susceptible species, including $M$. fatua, $H$. tiliaceus, and D. samoense. According to Webb et al. (1999), M. fatua was the most abundant species in the lowland forests of American Samoa. Neil (1986) found that 40\% of infected trees in Pentecost Island's natural forest were $M$. fatua and $M$. fatua var. papuana. He suggested that this species was "preferentially colonized" by $P$. noxius. In mahogany plantations of Fiji, Singh and coworkers (1980) identified 15 native forest species as sources of infection in 44 disease centers: infection in 18 centers was initiated by Myristica castaneaefolia A. Gray. In our surveys, $M$. fatua accounted for $25 \%$ of all diseased trees and $23 \%$ of $P$. noxius infections in secondary valleys.

Single-species cropping systems are known for their vulnerability to disease (Fry 1982). Of 62 infection centers at all survey sites on Tutuila Island, $72 \%$ were composed of either a single tree species or a majority of the same species. Bloomberg (1990) reported a higher incidence of $P$. weirii in Canadian plantations where Douglas-fir was dominant than in plantations with mixed stands. In the South Pacific, the incidence and spread of $P$. noxius is usually reported for and most severe in single-species plantations on cleared forest sites (Thrower 1965, Singh et al. 1980, Bolland 1984, Neil 1986, Ivory 1990). Webb and Fa'aumu (1999) suggested that clearing of 
tropical forests by natural or human means leads to reestablishment by a few successional species. In secondary forests, $H$. tiliaceus is an important colonizing species (Webb et al. 1999), and D. samoense may dominate alluvial valleys (Whistler 1994). The high percentage of infection among these species and $M$. fatua could emphasize their prevalence in disturbed communities, susceptibility to $P$. noxius, virulence of the pathogen in these sites, or a combination of these factors.

Based on their findings, Nandris et al. (1987) believed that infection of rubber trees in Africa was affected by differences in susceptibility within Hevea sp. and by intraspecific variability in pathogenicity of $P$. noxius isolates. In contrast to these findings, Chang (1995) tested 12 isolates of $P$. noxius on nine host species and found no host specificity demonstrated by the fungus. Similar testing is needed to determine differences in host susceptibility to $P$. noxius in American Samoa, intraspecific variation in pathogenicity of fungal isolates, or both.

No large centers of brown root rot disease have been observed or reported on Tutuila Island. However, the relatively high levels of infection in disturbed forest sites and the broad host range of $P$. noxius suggest future problems for landscape plantings and local agriculture as people clear forest land to build houses and plant crops.

\section{ACKNOWLEDGMENTS}

My thanks to the Land Grant survey team, O. C. Steele, and M. Schmaedick for their support. Thanks also to J. Seamon, American Samoa Government, Department of Marine and Wildlife Resources, for site access, and to J. Micales, USDA Forest Products Laboratory, for verification of fungus identifications.

\section{Literature Cited}

Adaskaveg, J. E., and J. M. Ogawa. 1990. Wood decay pathology of fruit and nut trees in California. Plant Dis. 74:341-352.

Ann, P. J., H. L. Lee, and J. N. Tsai. 1999. Survey of brown root disease of fruit and ornamental trees caused by Phellinus noxius in Taiwan. Plant Pathol. Bull. 8 (2) (abstract).

Bloomberg, W. J. 1990. Effect of stand conditions on advance of Phellinus weirii in Douglas-fir plantations. Phytopathology 80:553-559.

Bolland, L. 1984. Phellinus noxius: Cause of a significant root-rot in Queensland hoop pine plantations. Aust. For. 47 (1): 2-10.

Chang, T. T. 1995. Decline of nine tree species associated with brown root rot caused by Phellinus noxius in Taiwan. Plant Dis. 79:962-965.

1996. Survival of Phellinus noxius in soil and in the roots of dead host plants. Phytopathology 86:272-276.

Chang, T. T., and W. W. Yang. 1998. Phellinus noxius in Taiwan: Distribution, host plants and the $\mathrm{pH}$ and texture of the rhizosphere soils of infected hosts. Mycol. Res. 102 (9): 1085-1088.

Cole, T. G., N. McKay, C. D. Whitsell, A. H. Ambacher, and W. A. Whistler. 1988. Vegetation survey and forest inventory, American Samoa. Pacific Southwest Forest and Range Experiment Station, Berkeley, California.

Corner, E. J. H. 1932. The identification of the brown-root fungus. Gard. Bull. Straits Settlem. 5 (12): 317-350.

Farr, F., G. Bills, G. Chamuris, and A. Rossman. 1995. Fungi on plants and plant products in the United States. APS Press, St. Paul, Minnesota.

Fidalgo, O. 1968. Phellinus pachypbloeus and its allies. Mem. N. Y. Bot. Gard. 17 (2): 109147.

Fry, W. E. 1982. Principles of plant disease management. Academic Press, New York.

Greenwood, J. J. D. 1996. Basic techniques. Pages 11-110 in W. J. Sutherland, ed. Ecological census techniques: A handbook. Cambridge University Press, Cambridge, United Kingdom.

Haase, P. 1995. Spatial pattern analysis in ecology based on Ripley's K-function: Introduction and methods of edge correction. J. Veg. Sci. 6:575-582.

Hodges, C. S., and J. A. Tenorio. 1984. Root disease of Delonix regia and associated tree 
species in the Mariana Islands caused by Phellinus noxius. Plant Dis. 68:334-336.

Ivory, M. H. 1990. Brown root-rot of tropical forest trees in the South-West Pacific region. Pages 100-106 in C. Hutacharern, K. G. MacDicken, M. H. Ivory, and K. S. S. Nair, eds. Proceedings of the IUFRO workshop on pests and diseases of forest plantations. Food and Agricultural Organization of the United Nations, Bangkok, Thailand.

McKenzie, E. H. C. 1996. Fungi, bacteria and pathogenic algae on plants in American Samoa. Technical Paper No. 206. South Pacific Commission, Noumea, New Caledonia.

Nakamura, S. 1984. Soil survey of American Samoa. USDA Soil Conservation Service, U.S. Government Printing Office, Washington, D.C.

Nandris, D., M. Nicole, and J. P. Geiger. 1987. Root rot disease of rubber trees. Plant Dis. 71:298-306.

Neil, P. E. 1986. A preliminary note on Phellinus noxius root rot of Cordia alliodora plantings in Vanuatu. Eur. J. For. Pathol. 16:274-280.

Nicole, M., H. Chamberland, D. Rioux, X. Xixuan, R. A. Blanchette, J. P. Geiger, and G. B. Ouellette. 1995. Wood degradation by Phellinus noxius: Ultrastructure and cytochemistry. Can. J. Microbiol. 41:253-265.

Pegler, D. N., and J. M. Waterston. 1968. Phellinus noxius. CMI (Commonw. Mycol. Inst.) Descr. Pathog. Fungi Bact. No. 195.

Ripley, B. D. 1981. Spatial statistics. J. Wiley \& Sons, New York.

Singh, S., I. Bola, and J. Kumar. 1980. Diseases of plantation trees in Fiji Islands: I. Brown root rot of mahogany (Swietenia macropbylla King). Indian For. 106:526532.

Thrower, L. B. 1965. Parasitism of cacao by Fomes noxius in Papua-New Guinea. Trop. Agric. (Trinidad) 42 (1): 64-67.

Trujillo, E. E. 1971. The breadfruit diseases of the Pacific Basin. Information Document No. 27. South Pacific Commission, Noumea, New Caledonia.

Volk, R. D., P. A. Knudsen, K. D. Kluge, and D. J. Herdrich. 1992. Towards a territorial conservation strategy and the establishment of a conservation areas system for American Samoa. Le Vaomatua, Inc., Pago Pago, American Samoa.

Webb, E. L., and S. Fa'aumu. 1999. Diversity and structure of tropical rain forest of $\mathrm{Tu}$ tuila, American Samoa: Effects of site age and substrate. Plant Ecol. 144:257-274.

Webb, E. L., J. S. Brooks, and M. L. Jensen. 1999. Effects of topography on rain forest tree community structure and diversity in American Samoa, and implications for frugivore and nectarivore populations. J. Biogeogr. 26:887-897.

Whistler, W. A. 1993. Botanical survey of the Ottoville lowland forest, Tafuna, Tutuila, American Samoa. Department of Marine and Wildlife Resources, Pago Pago, American Samoa.

- 1994. Botanical inventory of the proposed Tutuila and Ofu units of the National Park of American Samoa. Technical Report No. 87, Cooperative National Park Resources Studies Unit, University of Hawai'i at Mānoa, Honolulu.

Wingert, E. A. (Project Director). 1981. A coastal zone management atlas of American Samoa. University of Hawai'i Cartographic Laboratory, Honolulu. 